\title{
ПРИКМЕТНЇЦКИ ПРИСЛОВНЇКИ У РУСКИМ ЯЗИКУ
}

\begin{abstract}
Абстракт: У роботи ше анализує присловнїки прикметнїцкого походзеня. Руша ше од рижних теорийох котри пояшнюю походзенє тей файти присловнїкох. Сама анализа дзелї прикметнїцки присловнїки на два часци. У першей гевти котри створени през адвербиялизацию, т.є. преходзенє зоз прикметнїкох до присловнїкох "замарзованьом" дзепоєдней припадковей форми прикметнїка. У таким процесу нє лєм же ше окаменює одредзена морфологийна форма, алє ше и меня семантика слова. Таки адвербиялизовани присловнїки дзелїме на два часци: на гевти котри настали зоз просту и зложену адвербиялизацию. До другей групи вошли присловнїки котри настали морфологийно, т.є. найчастейше кед адвербиялизовани форми уж постали потвердзени модел по котрим ше творя присловнїки, лєбо зоз додаваньом инших афиксох.
\end{abstract}

Ключни слова: присловнїк, прикметнїк, адвербиялизация, морфология, афикс.

Присловнїки - рижнородна файта словох, и по своїм способу твореня, и по походзеню, и по морфологийних характеристикох. Характерне за нїх то же ше нєшка присловнїки можу твориц од практично шицких полнозначних файтох словох. А кажда зоз тих полнозначних файтох словох ма свойо специфични модели твореня присловнїкох. У тей роботи преанализуєме прикметнїцки присловнїки у руским язику. Творенє присловнїкох $з$ прикметнїкох барз продуктивне и фреквентне нє лєм у нашим язику. Та и у шицких славянских язикох то єден з найпродуктивнєйших способох пополньованя групи присловнїкох. И нєшка просто нєвичерпни можлївосци твореня нових присловнїкох зоз прикметнїкох. Модели по котрих ше таки присловнїки творя стабилни, стари и у нашим язику, як виглєдованя указали, нє так ше лєгко меняю (Тимко-Дітко, 116-126).

Нє шицки таки прикметнїцки присловнїки єднаки, розликуєме даскельо пасма словотвору.

Походзенє присловнїкох прикметнїцкого походзеня у науковей ше литератури толкує на вецей способи. Мож видвоїц даскельо напрямки у теорийох. 
Перша и найрозширенша теория у славянскей язичней литератури виводзи таки присловнїки зоз формох косих припадкох кратких прикметнїкох хлопского и штреднього роду з применовнїками и без нїх (Бевзенко, 382).

Друга теория руша од твердзеня О. Потебнї, же “шицки славянски присловнїки на -о,-е (како, тако, тихо, много...) прешли през меновнїки штреднього роду акузатива" (Потебня, 53). Сй прихильнїки твердза же присловнїки прикметнїцкого походзеня на -о створени нє $30 з$ одвитуюцих формох прикметнїкох, а зоз формох меновнїкох, як резултат субстантивациї кратких прикметнїкох (Брошняк, 225). Теория ше звичайно подкрипює зоз фактами 3 диялектох, ягод и зоз других славянских язикох. Заш лєм, у процесу субстантивациї тоти прикметнїки, як познате, доставаю узши, конкретнєйши змист, котри нє одвитує значеню одвитуюцих присловнїкох.

На основи субстантивациї прикметнїкох формулована и треца теория. Вона предпоставя же ше подобни лексеми зявели як резултат лексико-граматичней кондензациї синтагмох: наgлуі̄o < на gлуіи час; йо-новому < йо новому сйособу;... У твореню рижних адвербиялних моделох виглєдоваче видвоюю єдинки: час, место, звичай, способ, фарбу (Брошняк, 103). У таких случайох припадкове законченє постава средство твореня: зgалєка - з gaлєка... Дзепоєдни науковци квалификую тот процес як “уключенє”, т.є. розширенє значеня слова котре нє достава морфемне вираженє (Грещук, 38-42).

Присловнїки руского язика зме виписали зоз Руско-сербского словнїка. Спомедзи шицких виписаних присловнїкох видвоєли зме гевти котри створени зоз прикметнїкох. Анализу мож зробиц на вецей способи. Мож анализовац походзенє, паралели у других язикох, творенє... Видзи нам ше же би важни резултати дало и поровнованє присловнїкох котри вошли до словнїка, и гевтих котри ше зоз тей групи хасную у бешеди, створени су по истим моделу, а нєт их у словнїку. То шведочи и о продуктивносци моделох, фреквентносци хаснованя...

У тей анализи ми огранїчиме виглєдованє на способ твореня присловнїкох котри настали зоз прикметнїкох. Анализу прикметнїцких присловнїкох зробиме так же их подзелїме на два групи: таки цо су резултат процесу адвербиялизациї и таки котри створени морфологийно.

\section{1. ПРИКМЕТНЇЦКИ ПРИСЛОВНЇКИ СТВОРЕНИ ЯК РЕЗУЛТАТ АДВЕРБИЯЛИЗАЦИЇ.}

И факти 303 других славянских язикох шведоча же тот процес твореня присловнїкох давни, походзи ище зоз общеславянского часу (Бевзенко, 381). Ище О. Шахматов твердзел же ше прикметнїк адвербиялизує чим ше почнє розпатрац споза синтагми зоз предметом и нє як субєкт лєбо обєкт. (Брош- 
няк, 105). Муши ше наглашиц факт же ше процес адвербиялизациї кратких прикметнїкох на -o, -е, -и предлужовал до зявеня полних формох, точнєйше до часу кед ше конєчно закончел процес формованя основней категорийней атрибутивней ознаки и кед кратки форми цалком страцели зависносц од меновнїкох, на чиєй су основи створени. Праве ше теди случело прерастанє адвербиялизациї як морфологично-синтаксичного способу до морфологичного. Прето у праву тоти науковци, котри твердза же ше тераз вецей прикметнїцки присловнїки нє творя през адвербиялизацию. (СУЛМ, 28).

\section{1. Присловнїки, створени у процесу простей адвербиялизациї.}

До тей групи уходза присловнїки, котри настали як резултат адвербиялизациї прикметнїкох без участвованя применовніїкох.

- Найпродуктивнєйши способ словотвореня творя деривати кратких прикметнїкох штреднього роду у форми номинатива на -о (ягод и на Закарпатю (Пискач, 93)): блїзко, брияко, бруgно, вично, бизовно, іамишно, іанблїво, їлаg-

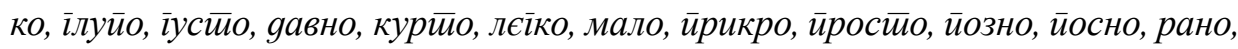
рияко, скуйо, слабо, илєбояно, смачно, йочно, йуньо, хмарно, чесно, чуgно, швияко, щииро и др. По походзеню вони дакедишнї кратки описни прикметнїки штреднього роду номинатива-акузатива єднини. Преходзенє до присловнїкох подобних прикметнїкох, спрам дзепоєдних науковцох, почало теди кед форма штреднього роду могла мац и значенє абстрактного меновнїка. До адвербиялизациї найчастейше и уходзели описни прикметнїки. Тот процес бул досц продуктивни и условени з нукашнїма причинами: у прасловнянским нє було досц слова котри означовали ознаку (Брошняк, 106).

Гоч, по наших замеркованьох, продуктивносц моделох твореня у бешедох нашого походзеня нє иста, точнєйше у нас звичайни способ твореня часто таки, яки у закарпатских бешедох ридки, лєбо наспак, заш лєм, тот модел зоз суфиксом -о продуктивни у шицких спомнутих бешедох. У словнїку, котри нам послужел як жридло фактичного материялу (Руско-сербски словнїк), нє зафиксовани звичайни присловнїки котри каждодньово хаснуєме: бруgно, іанблїво, іллаgко. То лєм шведочи о продуктивносци того моделу твореня и о факту же слово може буц и о морфологийним способу твореня. Точнєйше, суфикс -о мож спатрац як гомонимни суфикс, котри у старих присловнїкох лєм дакедишнє законченє прикметнїкох женского роду у форми котра прешла процес адвербиялизациї, а источашнє постал и словотворчи суфикс котри през процес морфологийного твореня може дац нови присловнїки, та є як таки продуктивни. Наприклад, можеме задумац нови присловнїки створени по тим моделу: компютерно, авияцийно, медзинародно... 
Таки присловнїки уношиме до другей, морфологийней групи твореня присловнїкох.

Семантика тих присловнїкох углавним одвитує общеукраїнским лексемом, заш лєм єст даскельо приклади, дзе праве семантика указує на походзенє зоз инших славянских язикох: рано, шлєбодно, худобно, смачно, лєбо на походзенє зоз других, нєсловянских язикох: мадярского: бизовно, їамишно, курито, фришко. Шицки тоти присловнїки, котри походза зоз меновнїкох пожичених маю свойо паралели и у бешедох Закарпатя (Чучка, 35).

Присловнїк вреgно, з часом достал семантику котру ма у сербским язику.

Присловнїки вельо, кельо, иелььо, пожичени у закарпатских бешедох 303 восточнословацкого диялекту, а форма компарациї присловнїка вещей пожичена, вироятно зоз польских бешедох, гоч постої и у лемковских и у закарпатских (Дзендзелївски, 13).

- Найдавнєйши присловнї̈и на -е творели ше ище у праславянским периодзе у процесу адвербиялизациї формох номинатива-акузатива кратких прикметнїкох штреднього роду мегких основох и формох компаратива (Бевзенко, 352). Спрам науковцох, тота група ше нєпреривно дополньовала на рахунок формох компаратива и суперлатива, котри ше творели од шицких квалитативних присловнїкох. Окрем того, спрам аналогиї у тей групи ше творели и присловнїки зоз суфиксом -е од основох твардих прикметнїкох и новотворох.

Присловнїки з формантом -е представени углавним у формох компарациї: їлїбе, їорше, красше, лєйше, менше, раgще, маю паралели и у закарпатских формох (Чучка, 36). Од общесловянских основох твардих прикметнїкох зачували зме лєм присловнїк gобре. Присловнїки на -е историйно повязани зоз старима нєчленима формами активних дїєприкметнїкох штреднього роду зоз суфиксами -уч (-юч), -ач (-яч), -ущ (-ющ). Присловнїки на -е настали на основи прикметнїкох на мегку основу (крашнє...), алє єст и прислов-

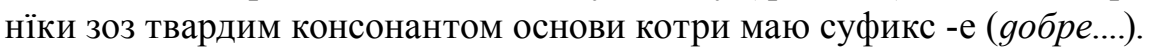

Даєдни присловнїки маю двояки форми - на -о и на -е/-є: pagocнo/pago-

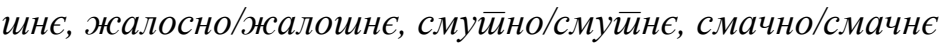

Найдавнєйши тип присловнїцких твореньох у руским язику творя прикменїцки присловнїки на -о, ридше -е: циххо, мало, ясно, .. Присловнїки на -о настали през адвербиялизацию дакедишнїх прикметнїцких формох штреднього роду. Дакедишнї прикметнїцки законченя у творчей структури прикметнїцких присловнїкох функционую як словотворни суфикси -о, -е. Практично шицки означуюци прикметнїки творя базу за творенє присловнїкох тей файти.

- Присловнїки на -и створени ище у праславянским периодзе (Бевзенко, 345). Векшина науковцох их виводзи зоз форми локатива єднини. Науковец 
А. Меє твердзи же локатив нє могол дац присловнїки способу дії прето ше у таких присловнїкох частково чува праиндоевропска фрома инструментала -о основох. Присловнїки на -и досц активно представени у славянских памяткох, заш лєм досц вчас их починаю поцисковац форми на -о, -е. После $\mathrm{XV}$ вику, як трима Безенко, вони уж нє зафиксовани (Бевзенко, 382). Прето их чуванє и активне хаснованє у бешеди вредни факт историї язика.

До старих прикметнїцких присловнїкох уходза и малочислени твореня на -и: рабски, чловечески, людски...нашлїдзени як адвербаялизовани форми инструменталу множини кратких прикметнїкох. Спрам аналогиї до таких присловнїкох, котри створени прейг адвербиялизациї, познєйше ше розвил модел суфиксалного и суфиксално-префиксалного твореня присловнїкох од прикметнїкох на -ск-: филозофски, йо-филозофски. Тоти форми створени зоз локатива єднини кратких прикметнїкох штреднього роду (добрі, красні, помалі), тота форма у югозаходних українских бешедох продуктивнєйша, алє заш лєм нє норма є стандардного українского язика (Пискач, 285).

Барз мала група присловнїкох, котри синхронийно випатраю як безсуфиксни основи, маме лєм присловнїк барз, котри квалификовани як заєднїцке словацко-польско-українске творенє вєдно з присловнїками вецей, вельо, вшелїяк, каgзи, кельо, нараз, ирраве, йаgзи, шумно (Дзендзелївски, 17). Шицки присловнїки, квалификовани як заєднїцки твореня функционую и у нас. Зоз нїх зме створели и деривати: іеваль-йамаль, іев-йам, іевка, іевйак,

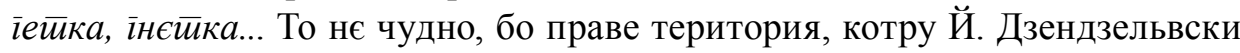
означує як простор моцних медзиязичних контактох, праве територия нашого походзеня. Цалком логичне же тоти присловнїки функционую у нашим язику, заш лєм мушиме наглашиц же ше вони потераз нє пременєли, нє заменєли и нє страцели. То вельо гутори о природи самих присловнїкох котри ше указую як стабилна файта словох.

У групи присловнїкох, котри створени у процесу простей адвербиялизациї, найвецей квалитативних: весело, іу $у \bar{u} о$, шиайно, $\bar{u} y \bar{u} o$, ... Тоти присловнїки активно ше хасную на означованє мери и ступню вираженя ознаки, характеру интензитету: мало, вельо, скуйо, йолно... Дзепоєдни означую стан чловека, природи и функционую у улоги главного члена безособових виреченьох. Вони ше волаю предикативи. То присловнїки: шлїзко, жимно, хмарно... Окрем того, вельке количество квалитативних присловнїкох ше явя у улоги предикативних: gурно, ясно, мило, циихо, масно, шмишно... Менша група квалитативних присловнїкох ше досц часто хаснує у функциї модалних: чистио, чесно, ясно, йочно... У складзе прикметнїцких присловнїкох на -о, -е, -и барз мало обставинових: обставиново-просторово ( gалєко, високо, нїзко, блїзко, gалєй); обставиново-часово ( gавно, gлуіо, мало, валєй, скорей). 


\section{2. Присловнїки, настали у процесу зложеней адвербиялизациї}

У славистики ше тот способ наволує “адвербиялизация у поєднаню 303 лексикализацию”, дзе ше под лексикализацию розуми “злїванє двох словох, 3 котрих єдно службове (применовнїк), до єдного, наприклад: навечар, вноци...” (Бевзенко, 380). Алє таке розуменє лексикализациї нє єдине. Окремни науковци тримаю, же лексикализация ма место кед ше окремна словоформа пременлївого слова видвоює зоз парадигми, преходзи до иншей файти словох, дзе достава ознаки котри у тей файти словох характеристични цалому слову (беїцом, моцно...). Зоз шицкого видно же лексикализация - то нє способ словотвореня, а скорей одредзени процес, механїзем. Праве прето ше термин “лексикализация” хаснує у широким значеню. Так лексикализация - то преходзенє службовей морфему (афикса) до слова, претворйованє синтагми до слова, а тиж фразеологизация, або наставанє идиоматичней синтагми 303 шлєбодней.

Науковци ше длуго намагаю одвитовац на питанє яки механїзем преходу применовнїцко-прикметнїкових синтагмох до присловнїкох, кед ше зна же ше прикметнїк як файта словох формовал на основи синтактичней категориї означеня и прето ше сам по себе нє могол хасновац зоз применовнїком.

Як познате, прикметнїк ше видвоєл на бази давней групи “менох" (Бевзенко, 163). Значи у вчасним праславянским чаше, кед тирвал тот процес, прикметнїк ище нє мал шицки свойо категориялни ознаки. Точнєйше, кратки прикметнїки у себе могли мац пообщуюце значенє предметносци. Праве теди кед починало формованє у кратких прикметнїкох атрибутивней ознаки як категорийней, а предметне значенє, нашлїдзене од менох ше ище нє страцело, праве теди ше и могла случиц адвербиялизация применовнїково-припадкових формох прикметнїкох.

У процесу зложеней адвербиялизациї видвоюєме присловнїки од котрих числену групу творя форми котри по походзеню прикметнїцко-припадково форми кратких прикметнїкох хлопского и штреднього роду:

1. у процесу адвербиялизациї кратки форми генитива прикметнїкох (хлопского и штреднього роду) з применовнїками до, з (c), за (gоїола,

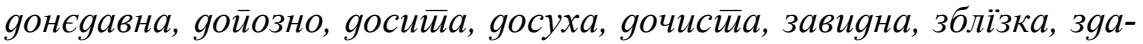
лєка, злєікка, знова, зрияка). Лєм присловнїк оggавна створени з помоцу применовнїка од.

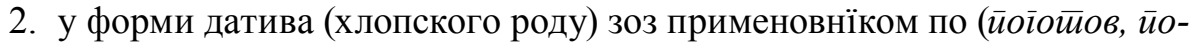

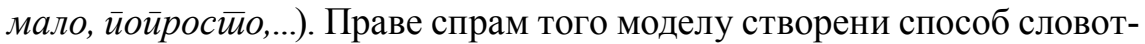
вору по-+-ому, котри условел дальше творенє присловнїкох през морфологийни способ. 
3. у форми акузатива кратких прикметнїкох штреднього роду зоз применовнїками у, за, на (набило, наблїзко, наgлуі̄o, начистио...). Безприменовнїкова форма акузатива штреднього роду кратких прикметнїкох иста як и одвитуюци присловнїк, та часто чежко одредзиц о котрей форми слово: чи то стара форма адвербиялизациї одвитуюцей синтагми, чи познєйша лексикализация применовнїка зоз уж формованим присловнїком. Праве прето єст рижни класификациї тих присловнїкох. Тоти присловнїки синоними гу гевтим котри створени през просту адвербиялизацию, заш лєм, окремни з нїх маю наглашену квалитативну ознаку.

4. огранїчену групу творя присловнїки, по походзеню зоз локатива $з о з$ применовнїком в, або на кратких прикметнїкох хлопско-штреднього роду (наяалєй, ...), по (иоомали, йо-люgски, йо-руски...)

Адвербиялизация прикметнїкових присловнїкох була барз продуктивна, спрам нєй ше розвили и дзепоєдни морфологийни способи деривациї. На основи адвербиялних поєднаньох формовали ше продуктивни творчи модели: суфикс -о, префикс по- + суфикс -ки, префикс по- + суфикс -ому, яки заєднїцки зашицки анализовани бешеди (Пискач, 288), а суфикс -ей уж наша иновация.

\section{2. ПРИКМЕТНЇЦКИ ПРИСЛОВНЇКИ КОТРИ НАСТАЛИ ПРЕЗ МОРФОЛОГИЙНИ СПОСОБ}

У роботох котри пошвецени словотвореню присловнїкох часто ше миша адвербиялизация и морфологийни способ твореня присловнїкох. Ми попробуєме преанализовац прикметнїцки присловнїки котри створени на морфологийни способ. Основни морфологийни способи твореня прикметнїцких присловнїкох котри видвоюєме: суфиксация (-о, -ей), префиксация (по-, нє-, за-), префиксално-суфиксални способ (по-+...-и; по-+ ... -им).

- Суфиксация

Як зме видзели, адвербиялизация була характеристична за кратки прикметнїково форми. Заш лєм у велїх анализованих присловнїкох видзелюю ше основи таких прикметнїкох, котри настали значно познєйше. Точнєйше, з часом адвербиялизовани припадково прикметнїцки форми створели нову нєпременлїву файту словох у котрей дакедишнї законченя постали словотворчи суфикси. Так ше створели модели твореня нових присловнїкох. Не мож нє обрациц увагу на тот факт. Праве прето видзелюєме и суфиксални способ словотвореня велїх групох присловнїкох. 
Присловнїки з суфиксом -о: безбожно, безконєчно, безиечно, безйлайно, бизовно, іамишно, заяармо, смачно, худобно, швияко...

Форми поровнованя зоз формантом -ей створени уж у нас: gалєй, блїжей, скорей, нӥжей, менєй... за нїх нєт паралели у заходноукраїнских бешедох. Українски еквиваленти маю суфикс -е: дале, ближе, ниже, више (Пискач, 285). У нас тот модел продуктивни и спрам нього ше нєпреривно творя и нови форми: од присловнїкох вчас - вчашей, од фришко - фришей... Тоти нови форми ище нє нормовани и нє унєшени до словнїка, заш лєм треба зазначиц же вони активно функционую у каждодньовей бешеди и же тот способ твореня присловнїкох постал хасновани модел.

Суфиксални присловнїки морфологийного типу створели ше на основи:

a) прикметнїкох чийо основи пожичени з мадярского (бизовно, їамишно, фришко, фино...), польского (смачно), словацкого (худобно...);

б) прикметнїки, котри настали на общеславянскей основи (бесконєчно, совисно...).

То нашо твореня, бо настали по правилох словотвореня присловнїкох нашого язика. Точнєйше, адвербиялизовани форми постали модел по котрим ше предлужело твориц нови присловнїки, та так, наприклад, -о, котре було дакедишнє законченє прикметнїкох штреднього роду постал словотворчи суфикс.

- Префиксация.

Прикметнїцки присловнїки з префиксом нє- маю значенє негациї основного значеня, характерного за одредзени присловнїк. Продуктивни модел твореня котри нєпреривно твори нови присловнїки.

Присловнїки $з$ префиксом по-. Таки присловнїки рижнородни. Видзелюєме найдавнєйши, котри створени на основу старих адвербиялизованих формох инструментала множини кратких прикметнїкох хлопского-штреднього роду -о- основох: иомилково, йойоли, йойолаgню, йойравgзе, йойрейта...

- Префиксално-суфиксални способ

Найпродуктивнєйши, спрам наших анализох модели: по- +-и; по- + -им.

Модел по- + -и. Тот модел ше формовал под вплївом старих адвербиялизованих формох инструментала множини кратких прикметнїкох хлопскогоштреднього роду зоз суфиксом -ск: йо-брайски, йо-женски, йо-люgски, йо-маяярски, иоо-руски..

На основи анализи прикметнїцких присловнїкох у руским язику заключуєме же:

- У руским язику єст даскельо продуктивни модели твореня нових форMOX. 
- То барз продуктивна и фреквентна файта присловнїкох котра ше нєпреривно пополнює зоз новима присловнїками, алє спрам познатих моделох.

- Заш лєм єст модели котри новостворени, и котри указую вельку виталносц у каждодньовим бешедним язику (присловнїки зоз суфиксом -ей).

- Видвойованє адвербиялизованих и морфологийних твореньох присловнїкох, дава можлївосц видвоїц и хронологийни групи присловнїкох, алє и модели твореня спрам фреквентносци и продуктивносци.

- Прикметнїцки присловнїки и у руским язику, ягод и у других славянских язикох, барз продуктивна група присловнїкох котра ма стабилни способи твореня нових лексемох.

\section{СКРАЦЕНЯ}

СУЛМ - Сучасна українська літературні мова (1994), ред. І. К. Білодід, Києв: Наукова думка

\section{ЛИТЕРАТУРА}

Бевзенко, С.П. (1960). Істиорична морфолоїія української мови, Ужгород: УжДУ.

Брошняк, О.Д. (1996). Прислівники в украӥнських іоворах Закарйаййя, дисертація на здобуття наукового ступеня кандидата Філологічних наук (рукопис).

Грещук, В.В. (1990). До питання про словотвір прислівників на -о, Мовознавсииво, 2, $45-58$.

Дзендзелівський, Й.О. (1959). Субстантивація в сучасній українській літературній мові, Наукові зайиси Ужі̄ородськойо Держсавноіо Універсииеейу, 37, 16-28.

Пискач, О. (1995). Відприкметникові прислівники в українських говорах Закарпаття, Молоgь-України, 280-291.

Потебня, А.А. (1958). Из заииисок йо русской іраммайике, Т. 1-2, Москва.

Рамач, Ю. (2002). Грамайика рускоїо язика, Београд: Завод за уџбенике и наставна средства.

Білодід, І. К. (ред). (1994). Сучасна украӥнська ліиеерайурна мова. Київ: Наукова думка.

Тимко-Дітко, О. (2014) Прислівники у говорі бачванських руснаків: склад і походження, Studia slovakistica, 15, 116-126.

Чучка, П.П. (1998) Прислівники старожитного периферійного говору, Науковий вісник

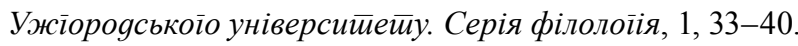


Oksana Timko Đitko

\title{
THE ADJECTIVAL ADVERBS IN THE RUSYN LANGUYGE
}

\begin{abstract}
SUMMARY
The adverbs of the adjective origin are being analyzed in this Paper. The starting point are different theories that explain the origin of that type of adjectives. The analysis itself divides the adjectival adverbs into two groups. The first group is made up of those made through adverbialization by transition of adjectives into adverbs, i.e. by "freezing" of a certain case form of the adjective. In that process, not only a certain morphological form is being petrified, but the semantics of the words is being changed too. Such adverbialized adverbs are being divided into two parts: the ones made by a simple and complex adverbialization. The second group is made up of adverbs made morphologically i.e. most often when the adverbialized forms have already become a usual model according to which adverbs are being formed (so that the former adjectival suffix became a formation suffix), or by adding of other affixes.
\end{abstract}

Key words: adverb, adjective, adverbialization, morphology, affix 